\title{
Comparison of Epigenetic and Genetic Alterations in Mucinous Cystic Neoplasm and Serous Microcystic Adenoma of Pancreas
}

\author{
Sang Geol Kim, M.D., Tsung-Teh Wu, M.D., Ph.D., Jae Hyuk Lee, M.D., Ph.D., \\ Young Kook Yun, M.D., Ph.D., Jean-Pierre Issa, M.D., Stanley R. Hamilton, M.D., \\ Asif Rashid, M.D., Ph.D. \\ Departments of Pathology (SGK, T-TW, JHL, SRH, AR) and Leukemia (J-PI), the University of Texas M.D. \\ Anderson Cancer Center, Houston, Texas; and Department of Surgery (YKY), Kyung Pook National \\ University Hospital, Taegu, Korea
}

Mucinous cystic neoplasms and serous microcystic adenomas account for the majority of cystic tumors of pancreas. Mucinous cystic neoplasms and serous microcystic adenomas have different frequencies of progression to malignancy. The genetic and epigenetic alterations of these tumors have not been studied in detail. In this study, we compared methylation status of $p 16, p 14, V H L$, and $p p E N K$ genes by methylation-specific PCR (MSP), and genetic alterations including $\mathrm{K}$-ras and $\beta$-catenin gene mutations, chromosome $3 p$ loss, and microsatellite instability in 15 mucinous cystic neoplasms (10 benign and 5 borderline) and 16 serous microcystic adenomas. There were no significant differences between mucinous cystic neoplasms and serous microcystic adenomas in methylation of $p 16(14 \%, 2 / 14$ and $12 \%, 2 / 16), p 14$ (15\%, $2 / 13$ and $37 \%, 6 / 16)$, VHL $(0 / 14$ and $7 \%, 1 / 14)$, and $p$ ENK $(0 / 14$ and $0 / 13)$, respectively. K-ras mutation was present only in mucinous cystic neoplasms but not in serous microcystic adenomas $(33 \%, 5 / 15$ versus $0 / 16 ; P=$ $.004)$. In addition, LOH at 3p25, the chromosomal location of $V H L$ gene, was present in $57 \%(8 / 14)$ of serous microcystic adenomas compared with in $17 \%(2 / 12)$ of mucinous cystic neoplasms $(P=.03)$. No $\beta$-catenin mutation, microsatellite instability, or mutation of transforming growth factor $\beta$ type II receptor was present in either type of tumors. In conclusion, K-ras mutations and allelic loss of VHL locus at 3p25, but not methylation, distinguished

\footnotetext{
Copyright (C) 2003 by The United States and Canadian Academy of Pathology, Inc.

VOL. 16, NO. 11, P. 1086, 2003 Printed in the U.S.A.

Date of acceptance: July 18, 2003.

Address reprint requests to: Asif Rashid, M.D., Ph.D., Department of Pathology, University of Texas M.D. Anderson Cancer Center, 1515 Holcombe Boulevard, Box 85, Houston, TX 77030-4095; fax: 713-792-5531; e-mail: arashid@mdanderson.org.

DOI: $10.1097 / 01 . M P .0000094088 .37888 . A 6$
}

mucinous cystic neoplasms and serous microcystic adenomas. The differences in genetic alterations but not epigenetic alterations may explain the pathogenesis and progression to malignancy of these cystic tumors of pancreas.

KEY WORDS: Genetic alterations, Methylation, Mucinous cystic neoplasm, Pancreas, Serous microcystic adenoma.

Mod Pathol 2003;16(11):1086-1094

Cystic tumors of the pancreas are relatively uncommon, accounting for less than $5 \%$ of pancreas exocrine tumors (1-5). Benign and borderline mucinous cystic neoplasms (ICD-O 8470/0 and ICD-O $8470 / 1$ ) and serous microcystic adenomas (ICD-O $8441 / 0$ ) account for most of the cystic tumors (2-4). These two tumors have differences in progression to malignancy and clinicopathological features (6). Mucinous cystic neoplasms are classified as benign, borderline (uncertain malignant potential), carcinoma in situ, and invasive carcinoma based on the severity of dysplasia of the lining epithelium or presence of stromal invasion $(2-4,7)$. In contrast, almost all serous microcystic adenomas are benign and rarely progress to malignancy (4). Distinguishing between these tumor types is clinically challenging but important because mucinous cystic neoplasms are more prone to recurrence if incompletely excised and more likely to become malignant.

There are differences in the genetic alterations in these cystic tumors. Activating mutations of $K$-ras are reported in both benign and malignant mucinous cystic neoplasms (8-12), but mutations of $K$-ras proto-oncogene and alterations of $p 53, p 16$ and DPC4 tumor suppressor genes are more frequently present in invasive mucinous cystic neoplasms $(9,11-13)$, suggesting stepwise increase in 
genetic alterations in malignant tumors. In contrast, these genetic alterations are not present in serous microcystic adenomas $(8-11,14)$, which can occur as a manifestation of von-Hippel-Lindau disease due to germline mutations of the VHL gene (15-17). In addition, sporadic serous microcystic adenomas frequently have allelic loss of chromosome 3p25 and infrequently, somatic VHL gene mutations $(15,18)$.

Other molecular abnormalities have been reported in various pancreatic neoplasms. Aberrant methylation of $\mathrm{CpG}$ islands is a molecular mechanism that leads to silencing of tumor suppressor genes such as $p 16$ and $p 14$ in a variety of cancers and precursor lesions (19-22). Recently, methylation of the $p p E N K$ gene encoding met-enkephalin was found to be frequent in ductal adenocarcinoma (23) and intraductal papillary-mucinous neoplasm of pancreas (24). Mutations in exon 3 of the $\beta$-catenin gene, involving the sites phosphorylated by GSK-3 $\beta$ for ubiquitination and degradation of $\beta$-catenin, stabilize $\beta$-catenin protein and in turn up-regulate the Tcf/Lef-1 family of transcription factors. $\beta$-catenin mutations have also been reported in diverse types of pancreatic carcinomas including pancreatoblastomas, pancreatic acinar cell carcinomas, and solid pseudopapillary carcinomas (25-28). Microsatellite instability due to alterations of mismatch repair genes such as human Mut L homologue 1 (hMLH1) and human Mut S homologue 2 (hMSH2) is present in medullary carcinomas of the pancreas $(28,29)$.

Methylation, $\beta$-catenin gene mutations, or microsatellite instability have not been studied in either mucinous cystic neoplasms or serous microcystic adenomas, and their roles in the pathogenesis of the two distinct pancreatic cystic tumors are unclear. In this study, therefore, we compared aberrant methylation of the $p 16, p 14$, ppENK, and VHL gene and genetic alterations including $K$-ras and $\beta$-catenin mutations, loss of chromosome 3p25, and microsatellite instability in mucinous cystic neoplasms and sporadic serous microcystic adenomas.

\section{MATERIALS AND METHODS}

\section{Patients and Specimens}

Fifteen pancreatic mucinous cystic neoplasms (ICD-O 8470/0 or ICD-O 8470/1) and 16 sporadic serous microcystic adenomas (ICD-O 8441/0) were identified from the surgical pathology files of the University of Texas M. D. Anderson Cancer Center (11 mucinous cystic neoplasms and 14 serous microcystic adenomas) and Kyung Pook National University Hospital, South Korea (4 mucinous cystic neoplasms and 2 serous microcystic adenomas) from patients undergoing resection between 1991 and 2001. Formalin-fixed, paraffin-embedded tumor and non-neoplastic tissue specimens were collected. The histopathology of the tumors was reviewed (Fig. 1), and mucinous cystic neoplasms were further classified as benign (ICD-O 8470/0) and borderline (uncertain malignant potential, ICD-O $8470 / 1$ ), as previously described (2-4). No mucinous cystic neoplasms with in situ carcinoma or invasive carcinoma were included in this study. Matching non-neoplastic pancreatic tissue was available from 13 patients with mucinous cystic neoplasms and 15 patients with serous microcystic adenomas. The study was approved by the Surveillance Committee (institutional review board) of the University of Texas M. D. Anderson Cancer Center.

\section{DNA Extraction}

Histologic sections were microdissected to obtain $>70 \%$ neoplastic cellularity. DNA was extracted from microdissected tumors and non-neoplastic tissues as described previously (30).

\section{Bisulfite Treatment of DNA and Methylation- Specific PCR}

Bisulfite treatment of DNA for methylation assays was carried out as described previously $(31,32)$. Methylation of the $p 16, p 14, p p E N K$, and VHL gene was determined by MSP as previously described $(19,21,23,33)$. Briefly, $2 \mu \mathrm{L}$ of bisulfite-treated DNA was used as template for PCR reactions using primers specific for methylated and unmethylated alleles (Table 1). PCR products from methylated and unmethylated reactions were electrophoresed on $6 \%$ nondenaturing acrylamide gels. The gels were stained with ethidium bromide, and the proportion of methylated allele compared with unmethylated allele was determined by densitometry. The DNA of colon cancer cell line RKO or SssI methylase-treated DNA (New England Biolabs, Beverly, MA) was used as positive control, and water, as negative control.

\section{Sequencing of Exon 1 of $K$-ras and Exon 3 of $\beta$-Catenin Genes}

Exon 1 of the $K$-ras proto-oncogene and exon 3 of the $\beta$-catenin gene were amplified by PCR and sequenced as described previously $(34,35)$. DNA sequencing was performed on the PCR product and amplification primers for each exon with a commercial DNA sequencing kit, according to the manufacturer's instructions (Applied Biosystems, Foster City, CA).

\section{Loss of Heterozygosity of chromosome 3p25}

Loss of heterozygosity ( $\mathrm{LOH}$ ) of chromosome 3 p25 was determined by use of three dinucleotide 

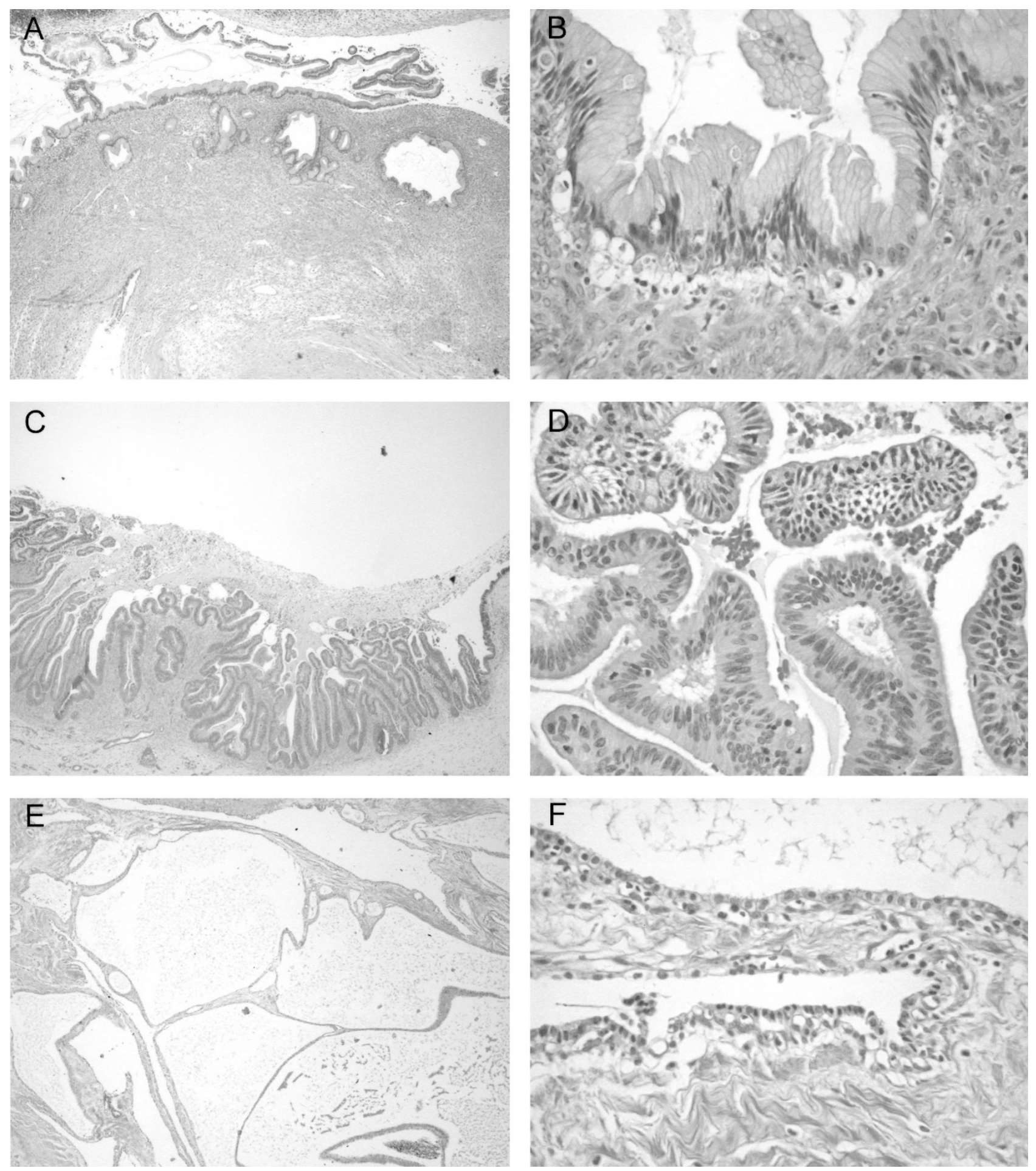

FIGURE 1. Histology of benign mucinous cystic neoplasm (A-B), borderline mucinous cystic neoplasm (C-D), and serous microcystic adenoma (E-F).

microsatellite markers near the VHL gene on chromosome 3 (D3S1110, D3S1038, and D3S1435) with PCR amplification using fluorescent dye-labeled primers (Invitrogen, Carlsbad, CA). The 5'oligonucleotide was end-labeled with 6-FAM fluorescent dye. PCR was performed in $15-\mu \mathrm{L}$ reaction volumes containing $20 \mathrm{ng}$ of DNA, $9 \mu \mathrm{L}$ of ABI Prism True Allele PCR Premix (Applied Biosystems, Foster City,
CA), and 5 pmol of each primer. PCR was performed using a GeneAmp PCR system 9700 thermal cycler (Applied Biosystems, Foster City, CA) with the following conditions: $95^{\circ} \mathrm{C}$ for 7 minutes; 3 cycles of $94^{\circ} \mathrm{C}$ for 1 minute, $58^{\circ} \mathrm{C}$ for 30 seconds, and $72^{\circ} \mathrm{C}$ for 45 seconds; 42 cycles of $93^{\circ} \mathrm{C}$ for 45 seconds, $54^{\circ} \mathrm{C}$ for 30 seconds, $72^{\circ} \mathrm{C}$ for 40 seconds; and final extension at $72^{\circ} \mathrm{C}$ for 30 minutes. A 


\begin{tabular}{|c|c|c|c|}
\hline & Primer Sequence & Annealing Temperature, Cycles & Function of the Gene Product \\
\hline p16 & $\begin{array}{l}\text { UF 5'-TTATTAGAGGGTGGGGTGGATTGT-3' } \\
\text { UR 5'-CAACCCCAAACCACAACCATAA-3' } \\
\text { MF 5'-TTATTAGAGGGTGGGGCGGATCGC-3' } \\
\text { MR 5'-GACCCCGAACCGCGACCGTAA-3' }\end{array}$ & $\begin{array}{l}60^{\circ} \mathrm{C}, 40 \\
65^{\circ} \mathrm{C}, 40\end{array}$ & $\begin{array}{l}\text { Cell cycle regulator, binds to CDK4 and CDK6, } \\
\text { inhibiting phosphorylation of retinoblastoma } \\
\text { protein }\end{array}$ \\
\hline p14 & $\begin{array}{l}\text { UF 5'-TTTTTGGTGTTAAAGGGTGGTGTAGT-3' } \\
\text { UR 5'-CACAAAAACCCTCACTCACAACAA-3' } \\
\text { MF 5'-GTGTTAAAGGGCGGCGTAGC-3' } \\
\text { MR 5'-AAAACCCTCACTCGCGACGA-3' }\end{array}$ & $60^{\circ} \mathrm{C}, 40$ & $\begin{array}{l}\text { Cell cycle regulator, binds to human double } \\
\text { minute2 (HDM2) gene product and prevents } \\
\text { ubiquitin mediated degradation of p53 }\end{array}$ \\
\hline ppENK & $\begin{array}{l}\text { UF 5'-TTGTGTGGGGAGTTATTGAGT-3' } \\
\text { UR 5'-CACCTTCACAAAAAAAATCAATC-3' } \\
\text { MF 5'-TGTGGGGAGTTATCGAGC-3' } \\
\text { MR 5'-GCCTTCGCGAAAAAAATCG-3' }\end{array}$ & $62^{\circ} \mathrm{C}, 40$ & $\begin{array}{l}\text { Encodes Met-enkephalin, which inhibits cell } \\
\text { proliferation }\end{array}$ \\
\hline$V H L$ & $\begin{array}{l}\text { UF 5'-GTTGGAGGATTTTTTTGTGTATGT-3' } \\
\text { UR 5'-GTTGGAGGATTTTTTTGTGTATGT-3' } \\
\text { MF 5'-GTTGGAGGATTTTTTTGTGTATGT-3' } \\
\text { MR 5'-GTTGGAGGATTTTTTTGTGTATGT-3' }\end{array}$ & $60^{\circ} \mathrm{C}, 40$ & $\begin{array}{l}\text { VHL protein ubiquitinates and degrades HIF-1 } \\
\text { transcription factor, constitutively activated HIF-1 } \\
\text { produces VHL disease associated tumors }\end{array}$ \\
\hline
\end{tabular}

Unmethylated forward, UF; unmethylated reverse, UR; methylated forward, MF; methylated reverse, MR.

$0.25-\mu \mathrm{L}$ aliquot of each fluorescent-labeled PCR product was combined with $12 \mu \mathrm{L}$ of formamide and $0.5 \mu \mathrm{L}$ of GENESCAN 400HD [ROX] size standard (Applied Biosystems). The samples were then subjected to capillary electrophoresis on an ABI 3700 DNA Analyzer using GENESCAN Analysis software (Applied Biosystems). Loss of a marker was considered to be present when the assay showed absence or decrease in intensity by $>50 \%$ of one of two alleles from a tumor sample as compared with the paired control non-neoplastic tissue. Complete or partial loss of chromosome 3p25 was based on the pattern of loss of the three markers.

Microsatellite Instability and Alteration of the Transforming Growth Factor $\beta$ Type II Receptor Gene

Microsatellite instability was evaluated by amplification of two mononucleotides repeats (BAT25 and BAT26) and three dinucleotide repeats (D2S123, D5S346, D17S250), as proposed by the NCI workshop (36), and alterations of the polyadenine tract of the transforming growth factor $\beta$ type II receptor (TGF $\beta$ RII) gene were evaluated using fluo- rescent dye-labeled primers as described previously (37). Allelic shift of a microsatellite marker was defined by the presence of at least one additional band in the tumor DNA as compared with in control DNA

\section{Statistical Analysis}

The differences in frequencies among clinicopathological factors and epigenetic and genetic alterations were analyzed by $\chi^{2}$ or Fisher's exact test. All statistical analyses were performed using the SPSS statistical program (SPSS Inc., Chicago, IL).

\section{RESULTS}

\section{Clinicopathological Characteristics of Patients and Tumors}

The clinicopathological characteristics of the patients and their tumors are summarized in Table 2. Mucinous cystic neoplasms were located mainly in the pancreatic body (80\%), whereas serous microcystic adenomas were evenly distributed among the head, body, and tail (44\% in head, $P=.002$ ). Thirty-

TABLE 2. Clinicopathological Features of Mucinous Cystic Neoplasms and Serous Microcystic Adenomas

\begin{tabular}{|c|c|c|c|}
\hline & $\begin{array}{l}\text { Mucinous cystic neoplasms }(\mathrm{n}=15) \\
\% \text { (fraction) }\end{array}$ & $\begin{array}{l}\text { Serous microcystic adenomas }(\mathrm{n}=16) \\
\% \text { (fraction) }\end{array}$ & $P$ Value \\
\hline Age (years $\pm \mathrm{SD}$ ) & $51.1 \pm 17.6$ & $56.9 \pm 11.8$ & NS \\
\hline Sex (\% female) & $87(13 / 15)$ & $75(12 / 16)$ & NS \\
\hline Size $(\mathrm{cm} \pm \mathrm{SD})$ & $4.7 \pm 3.4$ & $5.6 \pm 3.7$ & NS \\
\hline \multicolumn{4}{|l|}{ Site } \\
\hline Head & $0(0)$ & $44(7 / 16)$ & 0.002 \\
\hline Body & $80(12 / 15)$ & $31(5 / 16)$ & \\
\hline Tail & $20(3 / 15)$ & $25(4 / 16)$ & \\
\hline \multicolumn{4}{|l|}{ Histology } \\
\hline Benign & $67(10 / 15)$ & $100(16 / 16)$ & 0.02 \\
\hline Borderline & $33(5 / 15)$ & $0(0)$ & \\
\hline
\end{tabular}

\footnotetext{
${ }^{a}$ NS, not significant.
} 
three percent of mucinous cystic neoplasms were classified as borderline with uncertain malignant potential, but all serous microcystic adenomas were classified as benign $(P=.02)$.

\section{Aberrant Methylation of p16, p14, ppENK, and VHL Genes}

Examples of methylation are shown in Figure 2. One control pancreatic tissue adjoining a serous microcystic adenoma was methylated at p14, but no other control pancreatic tissues had methylation of the $p 14, p 16, p p E N K$, or $V H L$ genes.

Methylation of $p 16$ and $p 14$ was present in $14 \%$ $(2 / 14)$ and $15 \%(2 / 13)$, respectively, of mucinous cystic neoplasms, and in $12 \%(2 / 16)$ and $37 \%(6 / 16)$ of serous microcystic adenomas $(P=$ not significant, Table 3). Methylation of $V H L$ was present in $7 \%(1 / 14)$ of serous microcystic adenomas but was not found in mucinous cystic neoplasms (0/14). No methylation of $p p E N K$ was present in either $14 \mathrm{mu}-$ cinous cystic neoplasms or 13 serous microcystic adenomas. The frequencies of methylation of $p 16$, p14, and VHL were not different between mucinous cystic neoplasms and serous microcystic adenomas or between benign and borderline mucinous cystic neoplasms. The methylation of $p 16$ and $p 14$ was not concordant in either mucinous cystic neoplasms or serous microcystic adenomas.

\section{Genetic Alterations}

Mutation in exon 1 of the $K$-ras gene was present in $33 \%(5 / 15)$ of mucinous cystic neoplasms, but no mutations were found in serous microcystic adenomas $(0 / 16, P=.004$, Fig. 3A, Table 3). Four $K$-ras mutations were present in codon 12 and one in codon 13. There were no significant differences in mutation frequency between benign and borderline mucinous cystic neoplasms.

$\mathrm{LOH}$ of chromosome 3p25 was present in 57\% (8/14) of serous microcystic adenomas compared with only $17 \%(2 / 12)$ of mucinous cystic neoplasms $(P=.03$, Fig. 3B, Table 3). Allelic loss of chromosome 3p25 was more common in mucinous cystic neoplasms with $K$-ras mutations than tumors without $K$-ras mutations $(40 \%, 2 / 5$ versus $0 / 7, P=.04$ ) but was not associated with other clinicopathological characteristics in either type of cystic tumors.

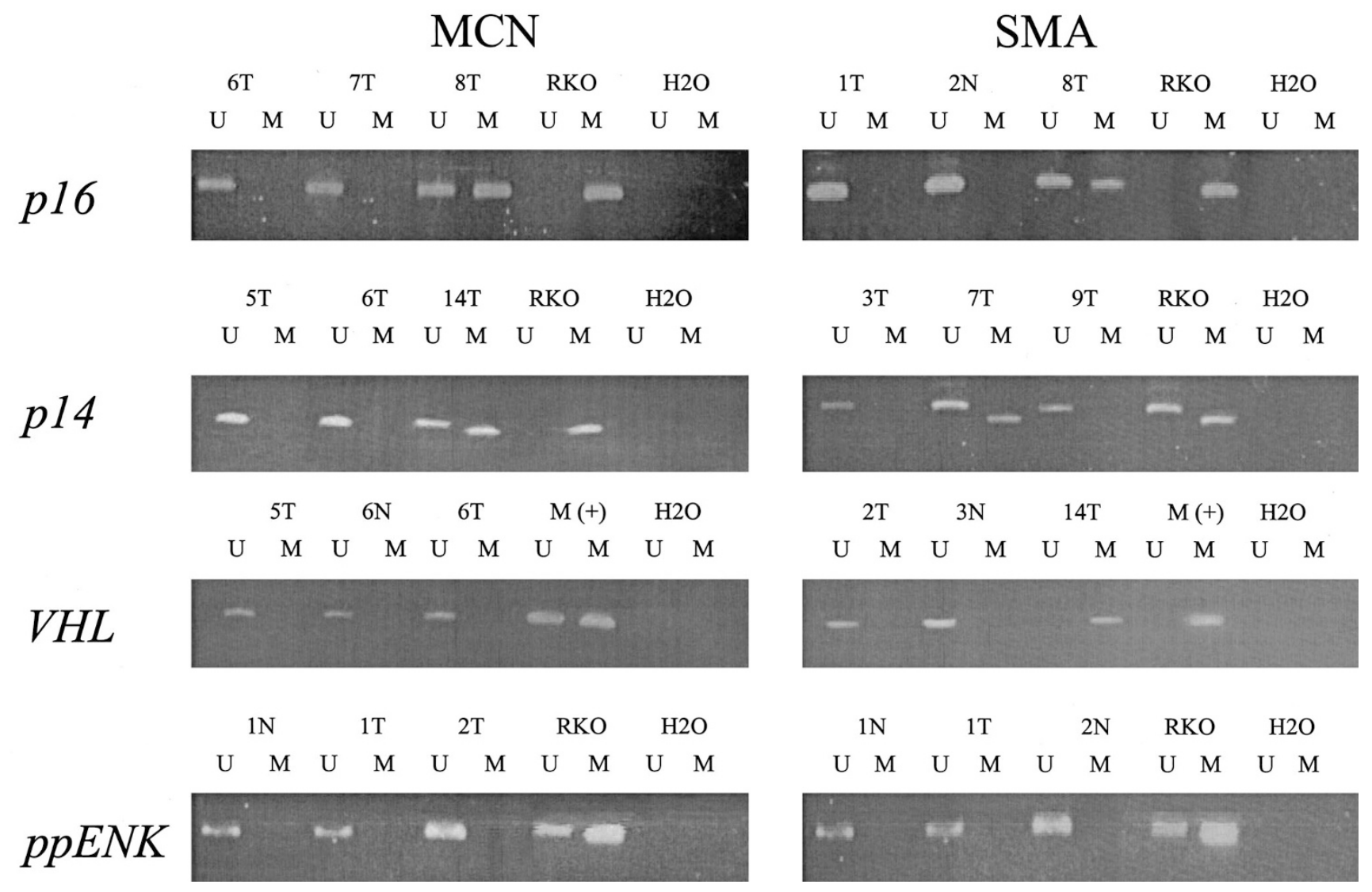

FIGURE 2. Methylation analysis of $p 16, p 14, p p E N K$, and $V H L$ genes by methylation-specific PCR. PCR products using primers for unmethylated $(\mathrm{U})$ and methylated $(\mathrm{M})$ alleles of bisulfite-treated DNA from tumor (T) and positive and negative control samples. MCN, mucinous cystic neoplasm; SMA, serous microcystic adenoma; RKO, positive control from colon cancer cell line; $\mathrm{M}(+)$, positive control DNA treated with Sss 1 methylase; $\mathrm{H}_{2} \mathrm{O}$, lanes without DNA used as negative control. MCN 8T and SMA 8T are methylated at $p 16$, MCN 14T and SMA 7T at $p 14$, and SMA 14T at VHL genes. All other samples shown in the gels are unmethylated. 


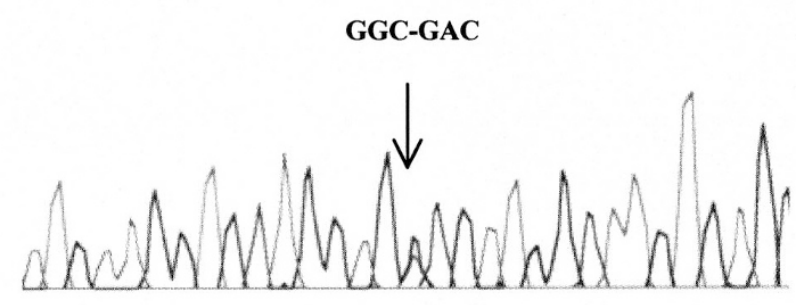

B

\section{D3S1110}

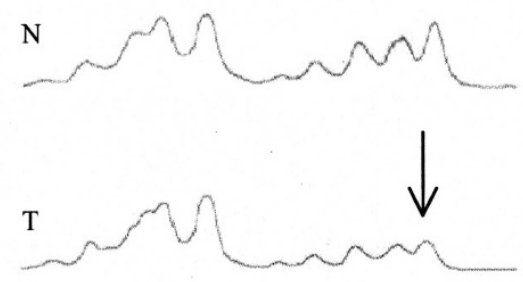

\section{D3S1435}
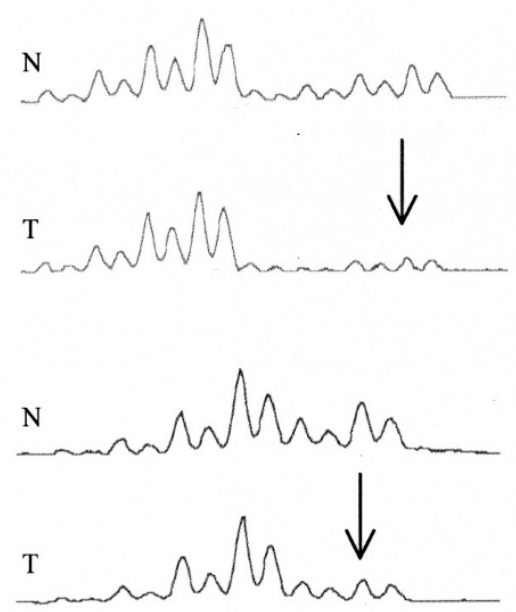

FIGURE 3. A, nucleotide sequencing of $K$-ras gene in mucinous cystic neoplasm. The mutation is indicated by an arrow. The wild-type and mutated nucleotide sequences are shown above the arrow. B, allelic loss of chromosome $3 p$ in mucinous cystic neoplasm and serous microcystic adenomas using dinucleotide microsatellite markers (D31110 and D31435). The lanes from normal DNA (N) have two alleles and the lanes from tumor DNA (T) show loss of one allele, indicated by arrows.

No mutations in exon 3 of $\beta$-catenin, microsatellite instability, or alterations of TGF $\beta R I I$ were present in mucinous cystic neoplasms or serous microcystic adenomas (Table 3).

\section{DISCUSSION}

Epigenetic alterations have not been studied previously in mucinous cystic neoplasms (benign and borderline) or sporadic serous microcystic adenomas. In our study, we found infrequent methylation of p16 and p14 in mucinous cystic neoplasms and serous microcystic adenomas, rare methylation of $V H L$ gene in serous microcystic adenomas, and no methylation of $p p E N K$ gene in either type of cystic tumor. These findings suggest that silencing of these genes by methylation may play a role in the tumorigenesis of some mucinous cystic neoplasms 


\begin{tabular}{|c|c|c|c|c|c|c|}
\hline & & \multicolumn{3}{|c|}{ Mucinous Cystic Neoplasms } & \multirow{2}{*}{$\begin{array}{c}\text { Serous } \\
\text { Microcystic } \\
\text { Adenomas } \\
(\mathrm{n}=16) \\
\% \text { (fraction) }\end{array}$} & \multirow[b]{2}{*}{$P$ Value } \\
\hline & & $\begin{array}{c}\text { Benign } \\
(\mathrm{n}=10) \\
\% \text { (fraction) }\end{array}$ & $\begin{array}{c}\text { Borderline } \\
\quad(\mathrm{n}=5) \\
\% \text { (fraction) }\end{array}$ & $\begin{array}{c}\text { Total } \\
(\mathrm{n}=15) \\
\% \text { (fraction) }\end{array}$ & & \\
\hline \multirow[t]{4}{*}{ Methylation } & p16 & $10(1 / 10)$ & $25(1 / 4)$ & $14(2 / 14)$ & $12(2 / 16)$ & NS \\
\hline & p14 & $22(2 / 9)$ & $0(0 / 4)$ & $15(2 / 13)$ & $37(6 / 16)$ & NS \\
\hline & VHL & $0(0 / 9)$ & $0(0 / 5)$ & $0(0 / 14)$ & $7(1 / 14)$ & NS \\
\hline & PpENK & $0(0 / 9)$ & $0(0 / 5)$ & $0(0 / 14)$ & $0(0 / 13)$ & NS \\
\hline \multirow[t]{5}{*}{ Genetic alterations } & K-ras & $30(3 / 10)$ & $40(2 / 5)$ & $33(5 / 15)^{a}$ & $0(0 / 16)^{a}$ & $0.004^{a}$ \\
\hline & 3p25 allelic loss & $20(2 / 10)$ & $0(0 / 2)$ & $17(2 / 12)^{a}$ & $57(8 / 14)^{a}$ & $0.03^{a}$ \\
\hline & $\beta$-catenin & $0(0 / 10)$ & $0(0 / 5)$ & $0(0 / 15)$ & $0(0 / 16)$ & NS \\
\hline & Microsatellite instability & $0(0 / 10)$ & $0(0 / 5)$ & $0(0 / 15)$ & $0(0 / 16)$ & NS \\
\hline & TGF $\beta$ RII & $0(0 / 10)$ & $0(0 / 5)$ & $0(0 / 15)$ & $0(0 / 16)$ & \\
\hline
\end{tabular}

NS, not significant.

${ }^{a}$ Mucinous cystic neoplasms versus serous microcystic adenomas.

and serous microcystic adenomas. However, there is no distinct methylation profile that can distinguish these two cystic tumor types.

The $\mathrm{Rb} / \mathrm{p} 16$ pathway is frequently inactivated in pancreatic carcinogenesis by homozygous/heterozygous deletions, mutations, and/or methylation (38). In our study, the frequency of methylation of the $p 16$ gene in mucinous cystic neoplasms and serous microcystic adenomas is similar to the reported frequencies of its methylation in pancreatic ductal adenocarcinomas, intraductal papillarymucinous neoplasm with carcinoma in situ or invasive carcinoma, and high-grade pancreatic intraepithelial neoplasia $(23,24,39)$. In contrast, previous studies of benign and borderline intraductal papillary-mucinous neoplasms and serous microcystic adenomas reported no methylation of $p 16$ gene but more frequent methylation of $p 16$ gene in mucinous cystic neoplasms with invasive carcinoma $(11,23)$. p14 ${ }^{\mathrm{ARF}}$ binds to human double minute 2 (HDM2) gene product to prevent HDM2 ubiquitin-mediated degradation of p53 (40). Methylation of $p 14$ has been reported in various cancers and in colitis-associated dysplasia and neoplasia in ulcerative colitis patients $(21,22)$, but we report for the first time p14 methylation in pancreatic neoplasms.

Recently, frequent tumor-specific methylation of $p p E N K$, which encodes met-enkephalin, has been reported in pancreatic ductal adenocarcinoma, intraductal papillary-mucinous neoplasm, and pancreatic ductal intraepithelial neoplasia $(23,24)$. Met-enkephalin is a growth inhibitory factor and decreases DNA synthesis, mitosis, and growth of cells (41). However, in the present study, no methylation of $p p E N K$ was present in either type of pancreatic cystic tumors. Thus, methylation of $p p E N K$ appear to be a selective event in pancreatic adenocarcinomas and intraductal papillary-mucinous neoplasms and may not play any role in the pathogenesis of MCNs and serous microcystic adenomas.
The complex of VHL protein, elongin C, elongin $\mathrm{B}$, and CLU2 enzymatically adds ubiquitin to HIF-1 transcription factor, which is degraded by proteosomal complex. Impaired binding of VHL protein to elongin C and HIF-1 due to mutation, or lack of VHL protein due to deletion or methylation, fails to ubiquitinate HIF-1. This alteration constitutively activates HIF-1 that promotes VHL diseaseassociated tumors (42). Syndromic serous microcystic adenomas are due to germline mutations of the VHL gene, and sporadic serous microcystic adenomas have somatic alterations of the VHL gene including deletion and mutations $(17,18)$. In our study, we found more frequent loss of chromosome 3 p25 in serous microcystic adenomas compared with mucinous cystic neoplasms. Methylation of the VHL gene was reported in sporadic and VHL disease-associated tumors such as renal cell carcinoma and hemangioblastoma (43). In the present study, methylation of the VHL gene was detected in only one serous microcystic adenoma, indicating that silencing of the $V H L$ gene by methylation has only a minor role in sporadic serous microcystic adenomas.

In our study, $K$-ras mutations were present in mucinous cystic neoplasms but not serous microcystic adenomas, and the frequency of $\mathrm{K}$-ras mutations was similar between benign and borderline subtypes of mucinous cystic neoplasms. Our finding corroborates results of previous studies that have shown less frequent $K$-ras mutations in benign and borderline subtypes of mucinous cystic neoplasms $(9,10,12)$. In contrast, the frequency of $\mathrm{K}$-ras mutations is more common in mucinous cystic neoplasms with in situ carcinoma or invasive carcinoma $(9,10-13)$. Our study and the previous studies $(9,11-13)$ support the concept that there is a progressive increase in the frequencies of the genetic alterations, including $K$-ras mutation, and p53, p16, and Dpc4 gene alterations in mucinous cystic tumors with histological progression: the ge- 
netic alterations are more common in mucinous cystic tumors with in situ carcinoma or invasive carcinoma than in benign and borderline subtypes.

We found that mucinous cystic neoplasms and serous microcystic adenomas lacked $\beta$-catenin mutation or microsatellite instability, in contrast to pancreatoblastomas, pancreatic acinar cell carcinomas, and solid-pseudopapillary carcinomas that have $\beta$-catenin mutation (25-27) and medullary subtypes of pancreatic carcinomas that have microsatellite instability (28).

It is important to distinguish mucinous cystic neoplasms from serous microcystic adenomas preoperatively because the former are more prone to recurrence if incompletely resected and can transform into invasive carcinoma. There is no distinctive methylation profile based on the limited number of CpG islands analyzed in the current study, but these two cystic tumor types have distinct histology and can be easily distinguished. Evaluation of $K$-ras gene mutation and chromosome 3p loss in aspiration biopsy specimens may be of help to distinguish mucinous cystic neoplasms from serous microcystic adenomas because of different frequencies in the tumor types: $K$-ras mutation favors mucinous cystic neoplasms, and 3p25 allelic loss without $K$-ras mutation favors serous cystic adenoma.

In conclusion, distinct genetic alterations rather than epigenetic alterations may account for the different pathogenesis of these two types of pancreatic cystic tumors. These findings may have diagnostic implications.

\section{REFERENCES}

1. Fernandez-del Castillo C, Warshaw AL. Cystic tumors of the pancreas. Surg Clin North Am 1995;75:1001-16.

2. Capella C, Solcia E, Klöppel G, Hruban RH. Serous cystic neoplasms of the pancreas. In: Hamilton SR, Aaltonen LA, editors. World Health Organization classification of tumors: pathology and genetics of tumors of the digestive system. Lyon, France: IARC Press; 2000. p. 231-3.

3. Zamboni G, Klöppel G, Hruban RH, Longnecker DS, Adler G. Mucinous cystic neoplasms of the pancreas. In: Hamilton SR, Aaltonen LA, editors. World Health Organization classification of tumors: pathology and genetics of tumors of the digestive system. Lyon, France: IARC Press; 2000. p. 234-6.

4. Solcia E, Capella C, Kloppel G. Tumors of the exocrine pancreas. In: Solcia E, Capella C, Klöppel G, editors. Atlas of tumor pathology: tumors of the pancreas. Washington, D.C.: Armed Forces Institute of Pathology; 1997. p. 31-53.

5. Klöppel G, Kosmahl M. Cystic lesions and neoplasms of the pancreas. The features are becoming clearer. Pancreatology 2001;1:648-55.

6. Fernandez-del Castillo C, Warshaw AL. Cystic neoplasms of the pancreas. Pancreatology 2001;1:641-7.

7. Wilentz RE, Albores-Saavedra J, Hruban RH. Mucinous cystic neoplasms of the pancreas. Semin Diagn Pathol 2000;17:3142.

8. Pellegata NS, Sessa F, Renault B, Bonato M, Leone BE, Solcia $\mathrm{E}$, et al. $K$-ras and $p 53$ gene mutations in pancreatic cancer: ductal and nonductal tumors progress through different genetic lesions. Cancer Res 1994;54:1556-60.

9. Bartsch D, Bastian D, Barth P, Schudy A, Nies C, Kisker O, et al. $\mathrm{K}$-ras oncogene mutations indicate malignancy in cystic tumors of the pancreas. Ann Surg 1998;228:79-86.

10. Yamaguchi K, Chijiiwa K, Noshiro H, Torata N, Kinoshita M, Tanaka M. Ki-ras codon 12 point mutation and p53 mutation in pancreatic diseases. Hepatogastroenterology 1999;46: 2575-81.

11. Gerdes B, Wild A, Wittenberg J, Barth P, Ramaswamy A, Kersting $\mathrm{M}$, et al. Tumor-suppressing pathways in cystic pancreatic tumors. Pancreas 2003;26:42-8.

12. Jimenez RE, Warshaw AL, Z'graggen K, Hartwig W, Taylor DZ, Compton CC, et al. Sequential accumulation of K-ras mutations and p53 overexpression in the progression of pancreatic mucinous cystic neoplasms to malignancy. Ann Surg 1999;230:501-9.

13. Iacobuzio-Donahue CA, Wilentz RE, Argani P, Yeo CJ, Cameron JL, Kern SE, et al. Dpc4 protein in mucinous cystic neoplasms of the pancreas: frequent loss of expression in invasive carcinomas suggests a role in genetic progression. Am J Surg Pathol 2000;24:1544-8.

14. Ishikawa T, Nakao A, Nomoto S, Hosono J, Harada A, Nonami T, et al. Immunohistochemical and molecular biological studies of serous cystadenoma of the pancreas. Pancreas 1998;16:40-4.

15. Moore PS, Zamboni G, Brighenti A, Lissandrini D, Antonello $\mathrm{D}$, Capelli $\mathrm{P}$, et al. Molecular characterization of pancreatic serous microcystic adenomas: evidence for a tumor suppressor gene on chromosome 10q. Am J Pathol 2001;158:317-21.

16. Hammel PR, Vilgrain V, Terris B, Penfornis A, Sauvanet A, Correas JM, et al. Pancreatic involvement in von HippelLindau disease: the Groupe Francophone d'Etude de la Maladie de von Hippel-Lindau. Gastroenterology 2000;119: 1087-95.

17. Mohr VH, Vortmeyer AO, Zhuang Z, Libutti SK, Walther MM, Choyke PL, et al. Histopathology and molecular genetics of multiple cysts and microcystic (serous) adenomas of the pancreas in von Hippel-Lindau patients. Am J Pathol 2000; $157: 1615-21$.

18. Vortmeyer AO, Lubensky IA, Fogt F, Linehan WM, Khettry U, Zhuang Z. Allelic deletion and mutation of the VHL tumor suppressor gene in pancreatic microcystic adenomas. Am J Pathol 1997;151:951-6.

19. Herman JG, Merlo A, Mao L, Lapidus RG, Issa JP, Davidson $\mathrm{NE}$, et al. Inactivation of the CDKN2/p16/MTS1 gene is frequently associated with aberrant DNA methylation in all common human cancers. Cancer Res 1995;55:4525-30.

20. Merlo A, Herman JG, Mao L, Lee DJ, Gabrielson E, Burger PC, et al. 5' CpG island methylation is associated with transcriptional silencing of the tumour suppressor $p 16 / C D K N 2 /$ MTS1 in human cancers. Nat Med 1995;1:686-92.

21. Esteller M, Tortola S, Toyota M, Capella G, Peinado MA, Baylin SB, et al. Hypermethylation-associated inactivation of p14(ARF) is independent of p16 (INK4a) methylation and p53 mutational status. Cancer Res 2000;60:129-33.

22. Sato F, Harpaz N, Shibata D, Xu Y, Yin J, Mori Y, et al. Hypermethylation of the p14 (ARF) gene in ulcerative colitisassociated colorectal carcinogenesis. Cancer Res 2002;62: 1148-51.

23. Fukushima N, Sato N, Ueki T, Rosty C, Walter KM, Wilentz $\mathrm{RE}$, et al. Aberrant methylation of preproenkephalin and p16 genes in pancreatic intraepithelial neoplasia and pancreatic ductal adenocarcinoma. Am J Pathol 2002;160:1573-81.

24. Sato N, Ueki T, Fukushima N, Iacobuzio-Donahue CA, Yeo CJ, Cameron JL, et al. Aberrant methylation of CpG islands in intraductal papillary mucinous neoplasms of the pancreas. Gastroenterology 2002;123:365-72. 
25. Abraham SC, Wu TT, Klimstra DS, Finn LS, Lee JH, Yeo CJ, et al. Distinctive molecular genetic alterations in sporadic and familial adenomatous polyposis-associated pancreatoblastomas: frequent alterations in the APC/ $\beta$-catenin pathway and chromosome 11p. Am J Pathol 2001;159:1619-27.

26. Abraham SC, Wu TT, Hruban RH, Lee JH, Yeo CJ, Conlon K, et al. Genetic and immunohistochemical analysis of pancreatic acinar cell carcinoma: frequent allelic loss on chromosome $11 \mathrm{p}$ and alterations in the $A P C / \beta$-catenin pathway. Am J Pathol 2002;160:953-62.

27. Abraham SC, Klimstra DS, Wilentz RE, Yeo CJ, Conlon K, Brennan M, et al. Solid-pseudopapillary tumors of the pancreas are genetically distinct from pancreatic ductal adenocarcinomas and almost always harbor $\beta$-catenin mutations. Am J Pathol 2002;160:1361-9.

28. Goggins M, Offerhaus GJA, Hilgers W, Griffin CA, Shekher M, Tang D, et al. Pancreatic adenocarcinomas with DNA replication errors $\left(\mathrm{RER}^{+}\right)$are associated with wild-type K-ras and characteristic histopathology: poor differentiation, a syncytial growth pattern, and pushing borders suggest $\mathrm{RER}^{+}$. Am J Pathol 1998;152:1501-7.

29. Yamamoto H, Itoh F, Nakamura H, Fukushima H, Sasaki S, Perucho M, et al. Genetic and clinical features of human pancreatic ductal adenocarcinomas with widespread microsatellite instability. Cancer Res 2001;61:3139-44.

30. Moskaluk CA, Kern SE. Microdissection and polymerase chain reaction amplification of genomic DNA from histological tissue sections. Am J Pathol 1997;150:1547-52.

31. Toyota M, Ahuja N, Ohe-Toyota M, Herman JG, Baylin SB, Issa JP. CpG island methylator phenotype in colorectal cancer. Proc Natl Acad Sci U S A 1999;96:8681-6.

32. Toyota M, Ahuja N, Suzuki H, Itoh F, Ohe-Toyota M, Imai K, et al. Aberrant methylation in gastric cancer associated with the CpG island methylator phenotype. Cancer Res 1999;59: $5438-42$.

33. Herman JG, Latif F, Weng Y, Lerman MI, Zbar B, Liu S, et al. Silencing of the VHL tumor-suppressor gene by DNA methylation in renal carcinoma. Proc Natl Acad Sci U S A 1994; 91:9700-4.
34. Chan AO, Broaddus RR, Houlihan PS, Issa JP, Hamilton SR, Rashid A. CpG island methylation in aberrant crypt foci of the colorectum. Am J Pathol 2002;160:1823-30.

35. Rashid A, Gao Y-T, Bhakta S, Shen M-C, Wang B-S, Deng J, et al. $\beta$-catenin mutations in biliary tract cancers: a population-based study in China. Cancer Res 2001;61:3406-9.

36. Boland CR, Thibodeau SN, Hamilton SR, Sidransky D, Eshleman JR, Burt RW, et al. A National Cancer Institute Workshop on Microsatellite Instability for cancer detection and familial predisposition: development of international criteria for the determination of microsatellite instability in colorectal cancer. Cancer Res 1998;58:5248-57.

37. Parsons R, Myeroff LL, Liu B, Willson JK, Markowitz SD, Kinzler KW, et al. Microsatellite instability and mutations of the transforming growth factor $\beta$ type II receptor gene in colorectal cancer. Cancer Res 1995;55:5548-50.

38. Schutte M, Hruban RH, Geradts J, Maynard R, Hilgers W, Rabindran SK, et al. Abrogation of the $\mathrm{Rb} / p 16$ tumorsuppressive pathway in virtually all pancreatic carcinomas. Cancer Res 1997;57:3126-30.

39. Ueki T, Toyota M, Sohn T, Yeo CJ, Issa JP, Hruban RH, et al. Hypermethylation of multiple genes in pancreatic adenocarcinoma. Cancer Res 2000;60:1835-9.

40. Zhang Y, Xiong Y, Yarbrough WG. ARF promotes MDM2 degradation and stabilizes p53. ARF-INK4a locus deletion impairs both the Rb and p53 tumor suppression pathways. Cell 1998;92:725-34.

41. Zagon IS, Smith JP, McLaughlin PJ. Human pancreatic cancer cell proliferation in tissue culture is tonically inhibited by opioid growth factor. Int J Oncol 1999;14:577-84.

42. Richards FM. Molecular pathology of von Hippel-Lindau disease and the VHL tumour suppressor gene. Exp Rev Mol Med 2001, available at: www-ermm.cbcu.cam.ac.uk/ 01002654h.htm

43. Prowse AH, Webster AR, Richards FM, Richard S, Olschwang $\mathrm{S}$, Resche F, et al. Somatic inactivation of the VHL gene in von Hippel-Lindau disease tumors. Am J Hum Genet 1997; 60:765-71. 